\title{
PERAMPASAN RUANG HIDUP DALAM MAKNA REFERENSIAL ALQURAN
}

\author{
Chafid Wahyudi \\ Sekolah Tinggi Agama Islam Al-Fithrah, Surabaya \\ hafiz_why@yahoo.co.id \\ Robbah Munjiddin Ahmada \\ Ma'had Aly Al Hasaniyyah, Tuban \\ robbah.ma@gmail.com
}

\begin{abstract}
Deprivation of the living sphere always interconnects with the power, precisely through a scenario of territorial and capitalist interests. In practical terms, deprivation of living space has neglected social aspects, as well as confirmed the occurrence of crisis at the social-ecological level. The crisis can also be categorized as the turbulent relationship between humans and humans with nature. In the Qur'anic referentiality, deprivation of living space is a kind of denial of the mandate of God. The essence of spreading mercy to all, as like giving rights to those who reserve, not doing unjust, no activities that damage and hurt anyone, humans, animals, nature, and all creatures, has been eliminated by the dominance of the sectoral ego. As a result, a form of injustice manifests a series of violence and destruction. As an essential factor in life, it is urgent to return the living space to its position as a social function attached to the material element. In this context, the social capital framework can be a node that could bring the community back to the trusted living, that the living sphere is a common need. The social capital framework will, in turn, bring back the social aspects that are absent from the material elements.
\end{abstract}

Keywords: The Qur'an, Living Sphere, Social-ecology, Social-capital.

Abstrak: Perampasan ruang hidup selalu berkelindan dengan kuasa, yakni melalui skenario kepentingan teritorial dan kapitalis. Dalam praksisnya, perampasan ruang hidup telah menihilkan aspek sosial, sekaligus mengonfirmasi akan terjadinya krisis pada tataran sosial-ekologi. Krisis juga bisa dikatagorikan mengarah pada kekacauan hubungan manusia antarmanusia dan manusia dengan alam. Dalam makna referensial Alquran, perampasan ruang hidup merupakan pengingkaran atas amanat yang telah digariskan oleh Allah. Hakikat menyebar rahmat kepada semua, seperti memberikan hak kepada yang berhak, tidak zalim, tidak merusak dan menyakiti kepada siapapun, tereliminir sebab dominasi ego sektoral. 
Akibatnya, bentuk kezaliman tercipta pada serangkaian kekerasan dan perusakan. Sebagai faktor penting dalam kehidupan, mengembalikan ruang hidup pada posisinya sebagai fungsi sosial yang melekat pada unsur material adalah tanggung jawab yang mendesak. Dalam konteks ini, kerangka social capital bisa ditempatkan sebagai simpul yang akan membawa komunitas masyarakat berada pada sebuah jaringan kesalingpercayaan, bahwa ruang hidup adalah kebutuhan bersama. Kerangka ini pada gilirannya akan menghadirkan kembali aspek sosial yang absen dari unsur material.

Keyword: Alquran, Ruang Hidup, Sosial-Ekologi, Social-capital.

\section{Pendahuluan}

Mendiskusikan "ruang hidup"1 sebagai hak milik bersama di negara kita selalu terbayangi logika kekuasaan. Kekuasaan di sini meminjam bahasa Nietszche, adalah "kehendak untuk benar" (the will to truth), yakni kehendak mengklaim kebenaran, dan dari kebenaran ini terwujud prosedur-prosedurnya. Semacam hubungan timbal balik antara kebenaran dengan mekanime percaturan kuasa yang menempatkan kebenaran diproduksi. Bersama logika ini, ruang hidup ditilap melalui dua skenario kepentingan, yaitu teritorial dan kapitalis. ${ }^{3}$ Jika yang pertama, identik dengan regulasi penyelenggara negara, yang terakhir kerja-kerja kapital, seperti korporasi dan sebagainya. Keduanya menjalankan aksinya dengan memproduksi standar kebenaran yang kemudian dikemas dan dihadirkan untuk merampas ruang hidup masyarakat.

Aksi di atas jelas menabrak kemanusiaan dan keadilan yang dicitacitakan oleh Negara Kesatuan Republik Indonesia. Melansir teks tentang penyelenggaraan negara, sebagaimana tertera pada Undangundang Dasar (UUD) tahun 1945, yakni hukum dasar dan sumber

\footnotetext{
1 Secara definitif "ruang hidup" dapat diadaptasi dari Undang-undang Nomor 26 tahun 2007 tentang Penataan Ruang, Pasal 1 yang menyebut ruang sebagai "wadah yang meliputi ruang ruang darat, ruang laut, dan ruang udara, termasuk ruang di dalam bumi sebagai satu kesatuan wilayah, tempat manusia dan makhluk lain hidup, melakukan kegiatan, dan memelihara kelangsungan hidupnya". Lihat Myrna A. Safitri, Tristam Moeliono, "Bernegara Hukum dan Berbagai Kuasa dalam Urusan Agraria di Indonesia: Sebuah Pengantar" dalam Myrna A. Safitri, Tristam Moeliono (eds.), Hukum Agraria dan Masyarakat di Indonesia (Jakarta: HuMa; Van Vollenhoven Institute; KITLV-Jakarta, 2010), 7.

2 Ahmad Baso, Islam Pasca-Kolonial: Perselingkuhan Agama, Kolonialisme, dan Liberalisme (Bandung: Mizan, 2005), 39.

${ }^{3}$ Harvey, D., The New Imperialism (New York: Oxford University Press: 2003), 27.
} 
hukum tertinggi sekaligus pandangan hidup, cita-cita, dan falsafah, ${ }^{4}$ disebutkan di dalam pembukaannya:

...Kemerdekaan Kebangsaan Indonesia itu dalam suatu Undangundang Dasar Negara Indonesia, yang terbentuk dalam suatu susunan Negara Republik Indonesia yang berkedaulatan rakyat dengan berdasarkan kepada: Ketuhanan Yang Maha Esa, Kemanusiaan yang adil dan beradab, Persatuan Indonesia, dan Kerakyatan yang dipimpin oleh hikmat kebijaksanaan dalam Permusyawaratan/Perwakilan, serta dengan mewujudkan suatu Keadilan sosial bagi seluruh rakyat Indonesia." 5

Bahan refleksi atas pembukaan UUD 1945 tersebut, secara tegas telah tertulis, penyelenggaraan Negara didasarkan pada "Kemanusiaan yang Adil dan Beradab" dan "Keadilan Sosial bagi Seluruh Rakyat Indonesia." Nilai kemanusiaan yang dipadukan dengan nilai keadilan itu menjadi prototype bahwa secara prinsipil, penyelenggaraan Negara tidak boleh melanggar keduanya. Ketentuan yang demikian, sayangnya, bertolak belakang dengan apa yang dirasakan masyarakat. Dalam beberapa kasus, justru tersirat pesan bahwa nilai tersebut "tak lagi bernilai". Di antara indikator "tak lagi bernilai"-nya nilai yang dimaksud, bisa dilihat dari massifnya pencideraan nilai-nilai kemanusiaan dan keadilan, baik secara langsung maupun tidak langsung. Ironisnya, tidak sedikit dari aktor pelanggar itu adalah para penyelenggara Negara sendiri.

Catatan kritis Walhi menuturkan, adanya tata kelola wilayah yang hanya berorientasi pada keuntungan, menegaskan sinyal kedaulatan pangan dan keselamatan ekologis Mataraman semakin buruk. Catatan Walhi ini didasarkan pada kajian atas regulasi-regulasi yang dikeluarkan pemerintah, baik pusat atau daerah. Salah satu contohnya adalah kenyataan bahwa luas pertambangan di Jawa Timur mencapai $12 \%$ dari total luasan wilayah Jawa Timur. Luas wilayah pertambangan ini, sudah separuh lebih dari besaran wilayah pertanian di Jawa Timur, yakni 21\%. Tentu dalam hal ini, Mataraman menjadi satu contoh kawasan (berpotensi konflik) dari sekian kawasan di Indonesia. ${ }^{6}$

\footnotetext{
${ }^{4}$ Majelis Permusyawaratan Rakyat Republik Indonesia, Undang-undang Dasar Negara Republik Indonesia Tahun 1945 (Jakarta: Sekretariat Jendral MPR RI, 2013), xv-xvi.

5 Ibid., 115.

6 Wahana Lingkungan Hidup Indonesia (WALHI) Jawa Timur, Catatan Lingkungan Hidup Jawa Timur 2016; Mendiami Negeri yang Tak Layak. Huni (tt: WALHI Jawa Timur, 2016), 26. Terkait regulasi yang mendapat catatan kritis dari Walhi ini, selengkapnya bisa dilihat dalam "Catatan Lingkungan Hidup Jawa Timur 2016,"
} 
Pada tataran lapangan, perampasan ruang hidup senantiasa berkelindan dengan persoalan agraria. Dalam beberapa kasus, tatkala konflik agraria terjadi, seiring itu pula perampasan ruang hidup menjadi ancaman. Sebagai contoh, rilis Konsorsium Pembangunan Agraria (KPA) menyebut, bahwa dalam kehidupan sehari-hari sering terjadi irisan kepentingan antara pemilik hak atas tanah dan orang di sekitarnya. Semisal akses jalan masyarakat yang melalui tanah tersebut. Hal yang ingin ditegaskan, sebagaimana rilis KPA adalah "kepemilikan suatu hak atas tanah bukan berarti menjadikan tanah tersebut nihil dari fungsi ekologis, sosial, dan ekonomi." ${ }^{\prime 7}$ Penegasan ini menjadi sinyal akan rentan munculnya penghilangan ruang-ruang sosial disebabkan kepemilikan (mutlak) atas tanah. Akses jalan (yang akhirnya) tertutup, pencemaran dari aktivitas yang ada di tanah tersebut, dan beragam dampak sosial lainnya, menjadi hal yang tidak asing. Secara prinsip, sebagaimana tertuang dalam Pasal 6 Undangundang nomor 5 Tahun 1960 tentang Peraturan Dasar Pokok-pokok Agraria bahwa semua hak atas tanah mempunyai fungsi sosial. ${ }^{8}$

Berangkat dari tesis irisan kepentingan antara pemilik tanah dan masyarakat sekitar yang acap kali berujung pada "terampasanya ruang hidup", maka data konflik dari KPA ini menjadi warning bagi semua pihak. Catatan tahunan KPA memaparkan, jika di tahun 2015 terjadi 252 kasus konflik agraria, maka jumlah ini meningkat sekitar 450 kasus di tahun 2016. Rincian luasan konflik yang dimaksud sekitar 1.265.027 hektar, serta melibatkan 86.745 Kepala Keluarga (KK). Kasus konflik tertinggi berada di Riau dengan 44 kasus, disusul Jawa Timur 43 kasus dan Jawa Barat 38 kasus. Mayoritas konflik yang terjadi menyisir wilayah perkebunan sekitar 163 kasus, property 117 kasus, infrastruktur 100 kasus, kehutanan 25 kasus, tambang 21 kasus, migas 7 kasus, pesisir-kelautan 10 kasus, dan pertanian 7 kasus. ${ }^{9}$

dalam http://walhijatim.or.id/2017/01/mendiami-negeri-yang-tak-layak-hunicatatan-lingkungan-hidup-jawa-timur-2016/. Diakses pada 26 April 2020.

7 Konsorsium Pembaruan Agraria, "Perampasan Ruang Hidup oleh Pemilik Hak atas Tanah," dalam http://www.kpa.or.id/news/blog/perampasan-ruang-hidupoleh-pemilik-hak-atas-tanah/. Diakses 27 April 2020.

8 Dewan Kehutanan Nasional, Undang-undang nomor 5 Tabun 1960 tentang Peraturan Dasar Pokok-pokok Agraria dalam http://dkn.or.id/wp-content/uploads/2013 /03/Undang-Undang-RInomor-5-Tahun-1960-tentang-Pokok-Pokok-Dasar-

Agraria.pdf. Diakses pada 27 Mei 2017.

9 Konsorsium Pembaruan Agraria, "Perampasan Ruang Hidup". 
Sajian data di atas menyajikan benang merah, adanya pencideraan nilai kemanusiaan-keadilan. Pencideraan yang dimaksud terwujud dalam sekian regulasi (yang telah dikaji oleh Walhi) dan berlangsungya irisan kepentingan antara pemilik tanah dan orang di sekitarnya yang berujung terampasnya ruang hidup. Sebagai catatan, untuk melakukan kajian yang maksimal, maka perampasan ruang hidup dalam artikel ini akan difokuskan pada irisan kepentingan dalam penggunaan tanah. Pada level tertentu, mengambil sikap kritis dan melakukan proses check and balance sangatlah diperlukan dalam proses bernegara. Hal ini dilakukan untuk memberikan peringatan dan semacamnya, agar tidak semakin berlarut pengingkaran atas nilai yang telah menjadi konsensus.

Berangkat dari pembacaan di atas, dalam tulisan ini, elaborasi atas teks Alquran penting dilakukan sebagai proses dialogis antara teks agama dan realitas masifnya perampasan ruang hidup. ${ }^{10}$ Proses dialogis ini diharapkan dapat menjadi kerangka penjelasan tentang perampasan ruang hidup dalam perspektif makna referensial Alquran, termasuk bagaimana solusi Alquran atas persoalan tersebut.

\section{Artikulasi Ruang Hidup dan Perampasan Ruang Hidup}

Setiap warga negara mempunyai hak untuk menikmati ruang di sekitarnya. Tentu dengan catatan, selama penggunaan hak tersebut tidak merugikan orang lain. Secara fundamental, dalam hal terciptanya ruang, tanah menempati posisi yang sentral. Tertuang dengan jelas dalam Undang-Undang Nomor 5 Tahun 1960 tentang Peraturan Dasar Pokok-Pokok Agraria, tepatnya pasal 1 bahwa "seluruh bumi, air dan ruang angkasa, termasuk kekayaan alam yang terkandung di dalamnya merupakan kekayaan nasional." Pasal 2 menyebut bahwa kekayaan tersebut dikuasai oleh Negara, sebagai organisasi kekuasaan seluruh rakyat. Sementara pasal 4 menyebut, termasuk dalam bumi adalah tanah, berikut hak-haknya. Lebih rinci, pasal 6 Undang-undang (UU) yang sama menuturkan "setiap hak atas tanah mempunyai

\footnotetext{
10 Proses dialogis antara teks agama dan realitas ini sangat penting dilakukan. Menurut Ibrahim Abu Rabi', diskursus keislaman cenderung dikotomis dan hanya berpaku pada teks. Sehingga, kajian keislaman tampak usang dan krisis pembaharuan. Lihat: Hasan Mahfudh, “dari Ibrahim M. Abu Rabi' tentang Problematika Studi Islam Kontemporer," dalam Millati: Journal of Islamic Studies and Humanities, Vol.1, No.1 (2016), 34.
} 
fungsi sosial." ${ }^{11}$ Dalam penjelasannya, pasal 6 Undang-Undang Nomor 5 Tahun 1960 disebutkan;" "Ini berarti, bahwa hak atas tanah apapun yang ada pada seseorang, tidaklah dapat dibenarkan, bahwa tanahnya itu akan dipergunakan (atau tidak dipergunakan) sematamata untuk kepentingan pribadinya, apalagi kalau hal itu menimbulkan kerugian bagi masyarakat."

Secara jelas, UU mengamanatkan bahwa tanah tidak boleh nihil dari aspek sosial. Dapat dikatakan, kodrat dari tanah adalah melekat pada fungsi sosialnya. Dalam penjelasan selanjutnya (pasal yang sama), ketentuan fungsi sosial bukan bermaksud menghilangkan kepentingan perorangan, namun harus saling mengimbangi antara kepentingan masyarakat dan perorangan. Hal ini dilaksanakan untuk tujuan pokok "kemakmuran, keadilan dan kebahagiaan bagi rakyat seluruhnya" sebagaimana pasal 2 dan 3. Ketentuan selanjutnya dari fungsi sosial tanah tersebut adalah "akan diperhatikan kepentingan pihak yang ekonomis lemah."

Berkenaan dengan aspek sosial ini, maka bertalian dengan apa yang disebut ruang hidup. Meminjam penuturan Teguh Pambudi, ruang hidup adalah: "habitat, ekosistem, lingkungan tempat masyarakat tinggal...ruang hidup berarti terkait dengan pemakaian serta pemanfaataan sumber daya alam, yaitu air, tanah, udara."13 Pambudi melanjutkan, hal-hal yang material (berupa tanah, air, dan udara) tersebut, tidak bisa dilepaskan dari interaksi sosial di sekelilingnya. Dimensi material-sosial inilah yang kemudian mewujudkan ruang hidup. Aspek material sosial menjadi hal yang berkelindan, persis seperti amanat Pasal 6 Undang-Undang Nomor 5 Tahun 1960 di atas, bahwa "setiap hak atas tanah mempunyai fungsi sosial."

Kesatuan material-sosial ini acapkali hilang dengan penguasaan mutlak pada aspek material saja. Aspek sosial seolah menjadi hal lain yang sama sekali tidak ada sangkut pautnya dengan aspek material.

11 Undang-undang Nomor 5 Tahun 1960 tentang Peraturan Dasar Pokok-pokok Agraria, 2.

${ }^{12}$ Kementrian Keuangan, "Penjelasan atas Undang-undang Nomor 5 tahun 1960 tentang Undang-undang Pokok Agraria," dalam

http://www.jdih.kemenkeu.go.id/fullText/1960/5TAHUN 1960UUPENJEL.htm Diakses pada 27 April 2020.

13 Teguh Pambudi, "Yesus dan Keadilan Ruang Hidup," dalam https:/ / kristenhijau.wordpress.com/2017/05/25/yesus-dan-keadilan-ruang-hidup2/. Diakses pada 29April 2020. 
Merujuk pada penjelasan Pasal 6 Undang-Undang Nomor 5 Tahun 1960 tentang Peraturan Dasar Pokok-Pokok Agraria, maka secara yuridis, menihilkan fungsi sosial atas tanah, sama saja merampas ruang hidup masyarakat.

Penjelasan fungsi sosial yang melekat pada tanah ini, berkelindan dengan apa yang disebut sebagai "ruang hidup". Secara definitif, Undang-undang Nomor 26 tahun 2007 tentang Penataan Ruang pasal 1 menyebut ruang sebagai "wadah yang meliputi ruang ruang darat, ruang laut, dan ruang udara, termasuk ruang di dalam bumi sebagai satu kesatuan wilayah, tempat manusia dan makhluk lain hidup, melakukan kegiatan, dan memelihara kelangsungan hidupnya". ${ }^{14}$ Pendefinisian ruang tersebut, sebenarnya adalah bagian integral dari tanah yang berfungsi sosial sebagaimana amanat UUPA pasal 6 . Bahwa ruang, yang secara hakikat, tercipta—salah satunya-sebab tanah, adalah unsur yang menunjang kehidupan bagi manusia dan makhluk lain. Tentu berkenaan dengan pentingnya ruang bagi kehidupan ini, senyatanya ruang untuk hidup (baca: ruang hidup) tidak boleh dirampas. Bahwa "perampasan ruang hidup" memberikan pengertian adanya penihilan aspek sosial dari tanah.

Konsorsium Pembaruan Agraria (KPA) menyebut, bahwa harus dipahami jika suatu kegiatan tidaklah bisa dilepaskan dari ruang-ruang sosial. ${ }^{15}$ Penjelasan ini memberikan gambaran, bahwa "ruang hidup" yang merupakan bagian integral dari--fungsi sosial--tanah adalah satu hal yang niscaya dan tidak boleh dirampas. Satu hal yang ingin ditegaskan, sebagaimana rilis KPA, "kepemilikan suatu hak atas tanah bukan berarti menjadikan tanah tersebut nihil dari fungsi ekologis, sosial, dan ekonomi". ${ }^{16}$ Persis sebagaimana amanat UUPA pasal 6 sebagaimana telah dipaparkan sebelumnya.

Dalam tarikan sejarah, definisi "ruang hidup" tidak lepas dari skema kolonial. Misalnya, pemaknaan ruang hidup di Eropa, seperti Inggris dan Perancis telah menempatkan konsep tersebut ke dalam tataran geo-politiknya untuk pengembangan jajahannya. Tidak ketinggalan Jerman, pada perang dunia ke dua melakukan perluasan wilayahnya dengan mengkoloni Eropa agar menjadi satu bagian Jerman. Koloni Jerman tersebut merupakan pengenjawantahan ruang hidup yang disebutnya dengan lebensraum. Artinya, melalui ide

\footnotetext{
${ }^{14}$ Safitri \& Moeliono, "Bernegara Hukum," 7.

15 Konsorsium Pembaruan Agraria, Perampasan Ruang Hidup.

16 Ibid.
} 
lebensraum, Jerman yang menganggap dirinya sebagai bangsa Aria, merasa tidak memiliki ruang geografis yang cukup menampung rasnya, karenanya Jerman perlu memdapatkan tanah kolonial sebagai diekspoitasinya. ${ }^{17}$ Merujuk potret historis ini, maka jejak konsep ruang hidup sendari awal tidak lepas dari kuasa maupun dominasi atas kehidupan masyarakat lain.

Logika kolonial dalam bentuk kuasa seperti di atas, katakanlah merupakan bentuk kerja-kerja dengan cara yang kasar. Setelahnya, yakni memasuki fase era post-kolonial seperti sekarang, bukannya hilang akan tetapi skema kerja di atas diperhalus dengan menumpang gerbong prosedur kuasa melalui sektor teritorial dan kapitalis. ${ }^{18}$ Prosedur kuasa teritorial dan kapitalis yang mendekap ruang hidup di atas disebut oleh Eka Wahyu Setiawan dalam tulisannya sebagai "politik ruang". ${ }^{19}$ Dalam penjelasannya, kenapa mereka menjalakan aksinya, adalah bahwa kapitalis dengan sifatnya akan berusaha terus mengakumulasi lebih banyak (lagi) kapital. Sedangkan sektor teritorial, aksi itu dilakukan oleh para politisi dan negarawan demi melanggengkan atau memperbesar kekuatan kuasa atas negara, atau hal yang menguntungkan kelompok berkuasa, sehingga pada gilirannya memberikan keutungan pribadi atas harta kekayaan. Kedua sektor di atas, jika dimaknai perananya, maka kapitalis bergerak untuk berlomba menguasai ruang dan waktu, sedangkan politisi berusaha berkuasa atas teritori, yang keduanya memiliki relasi yang kuat untuk saling menguatkan dan menguntungkan satu sama lain. ${ }^{20}$

Dari pembacaan di atas, menunjukkan bagaimana sebuah skenario perampasan ruang hidup. Maka yang terjadi kemudian sosialekoligis tidak lagi berjalan secara alami, bahkan menuju pada kekacauan hubungan manusia antar manusia, manusia dengan alam. Melihat yang demikian, Murray Bookchin menjelaskan dengan baik penyebabnya. Ia melihat, bahwa krisis sosial-ekologis yang terjadi di masyarakat berakar dari dominasi manusia yang satu terhadap manusia yang lain. Pada gilirannya, dominasi ini menjadi faktor utama

\footnotetext{
${ }^{17}$ Lihat Agaton Kenshanahan, "Sejarah dan Pengertian Lebensraum," dalam http://abroadlythinking.blogspot.com/2015/08/sejarah-dan-pengertianlebensraum. html. Diakses pada 26 April 2020.

${ }_{18}$ Harvey, The New Imperialism, 27.

19 Eka Wahyu Setiawan, "Politik Ruang Hidup dan perampasan Ruang Hidup Masyarakat," dalam https://indoprogress.com/2018/03/politik-ruang-dalamperampasan-ruang-hidup-masyarakat/. Diakses pada tanggal 25 April 2020.

${ }^{20}$ Ibid.
} 
dalam melahirkan suatu bentuk dominasi manusia terhadap alam. ${ }^{21}$ Pandangan Murray Bookchin ini sekaligus merupakan penanda bahwa krisis ekologis (alam) adalah akibat bentuk dominasi manusia atas manusia lain, manusia atas alam yang terus dikembangkan demi memuaskan kekuasaan dengan cara kerja-kerja yang dikemas dalam narasi skenario kuasa.

Sampai di sini, jelas bahwa perampasan ruang hidup selalu melibatkan selubung kuasa, sebagai cerminan wujud dominasi atas yang lain. Fenomena perampasan ruang hidup tersebut tentu tidaklah nihil dari kontra di dalam memberikan pandangan kesepahaman sekaligus perlindungan di masyarakat, seperti halnya $\mathrm{HAM}^{22} \mathrm{Hal}$ ini patut diketengahkan terkait dengan HAM sebagaimana tesis awal artikel ini bahwa susunan Negara Republik Indonesia, di antaranya didasarkan pada "Kemanusiaan yang Adil dan Beradab" dan "Keadilan sosial bagi seluruh rakyat Indonesia".

Secara prinsipil, UUD 1945 menggariskan dalam pasal 28A bahwa "setiap orang berhak untuk hidup serta berhak mempertahankan hidup dan kehidupannya". ${ }^{23}$ Dalam pasal lain, tepatnya pasal 28J dinyatakan "setiap orang wajib menghormati hak asasi manusia orang lain dalam tertib kehidupan bermasyarakat, berbangsa dan bernegara. ${ }^{24}$ Normativitas teks tersebut secara tegas menyampaikan bahwa hak asasi manusia harus dihormati demi tercapainya kelangsungan mempertahankan hidup dan kehidupan manusia.

Pada level lebih teknis, kerangka HAM di Indonesia diatur dalam Undang-undang Republik Indonesia Nomor 39 Tahun 1999 tentang Hak Asasi Manusia (selanjutnya UU HAM). Berkaitan dengan yang dimaksud sebagai HAM, pasal 1 UU HAM menyebut "Hak asasi manusia adalah seperangkat hak yang melekat pada hakikat manusia sebagai makhluk Tuhan Yang Maha Esa dan merupakan anugerah-

${ }^{21}$ Ibid.

22 Historisitas Hak Asasi Manusia (HAM) sebagai consensus bersama mngalami perjalanan yang cukup Panjang. Dalam pemahaman Islam sendiri, perdebatan mengenai hubungan antara Islam dan HAM cukup beragam. Meski demikian, mayoritas pemikir Islam menyatakan bahwa Islam memiliki ajaran-ajaran tentang Hak Asasi Manusia, bahkan Islam lebih awal mendiskusikan sekaligus menghargaihak-hak yang melekat pada manusia. Lihat: Ahmad Mujahid, "Pandangan Mufasir Indonesia Terhadap Isu-Isu Hak Asasi Manusia," dalam Mutawatir: Jurnal Keilmuan Tafsir Hadith, vol. 9, no. 2 (2019), 198.

${ }_{23}$ Majelis Permusyawaratan Rakyat Republik Indonesia, Undang-undang Dasar, 153.

24 Ibid., 160. 
Nya yang wajib dihormati, dijunjung tinggi, dan dilindungi oleh negara, hukum, pemerintah, dan setiap orang demi kehormatan serta perlindungan harkat dan martabat manusia. ${ }^{25}$

Hak-hak asasi yang dimaksud, dalam pasal 1 di atas, dijelaskan lebih rinci dalam pasal 4 dengan;

Hak untuk hidup, hak untuk tidak disiksa, hak kebebasan pribadi, pikiran dan hati nurani, hak beragama, hak untuk tidak diperbudak, hak untuk diakui sebagai pribadi dan persamaan didepan hukum, dan hak untuk tidak dituntut atas dasar hukum surut adalah hak asasi manusia yang tidak dapat dikurangi dalam keadaan apapun dan oleh siapapun..$^{26}$

Tatkala hak-hak tersebut dibatasi, lebih-lebih dicabut, UU HAM mengakategorikannya sebagai pelanggaran atas HAM. Pelanggaran HAM dimaksud berupa: ${ }^{27}$

Setiap perbuatan seseorang atau kelompok orang yang termasuk aparat negara baik disengaja maupun tidak disengaja atau kelalaian, membatasi, dan atau mencabut hak asasi manusia seseorang atau kelompok orang yang dijamin oleh undangundang ini, dan tidak mendapatkan, atau dikhawatirkan tidak akan memperoleh penyelesaian hukum yang adil dan benar, berdasarkan mekanisme hukum yang berlaku.

Lebih lanjut dalam pasal 9 diamanatkan: (1) Setiap orang berhak untuk hidup, dan mempertahankan hidup dan meningkatkan taraf kehidupannya. (2) Setiap orang berhak hidup tenteram, aman, damai, bahagia, sejahtera lahir dan batin. (3) Setiap orang berhak atas lingkungan hidup yang baik dan sehat. ${ }^{28}$

Pada titik ini menjadi jelas dan terang bahwa hak hidup adalah bagian dari HAM. Maka dengan logika sederhana, merampas "ruang hidup" yang senyata-nyatanya membahayakan hak hidup adalah pelanggaran HAM dan sekaligus mengingkari hak untuk hidup. Satu hal yang tidak boleh dilupakan, dalam penegakan HAM, Indonesia mengamini Bangkok Declarations on Human Rights 1993 bahwa deklarasi HAM universal dalam konteks ASEAN "harus mempertimbangkan kekhususan yang bersifat regional dan nasional dan berbagai latar belakang sejarah, budaya, dan agama, sehingga penafsiran Deklarasi

\footnotetext{
25 Undang-undang Republik Indonesia Nomor 39 Tahun 1999 Tentang Hak Asasi Manusia, 2.

${ }^{26}$ Ibid.

27 Ibid., 3.

28 Ibid., 5 .
} 
HAM universal tidak seharusnya ditafsirkan dan diwujudkan secara bertentangan dengan ketiga latar belakang dimaksud". ${ }^{29}$

\section{Perampasan Ruang Hidup dalam Tinjauan Alquran}

Jika dalam tinjauan HAM, perampasan ruang hidup dapat dikategorikan sebagai pelanggaran HAM yang mengingkari kodrat manusia, lantas bagaimana Alquran membaca perampasan ruang hidup?

Dalam QS. al-Qașaș [28]: 77 disebutkan:

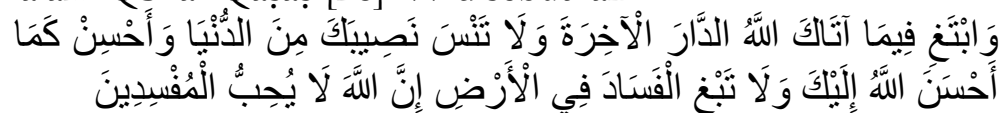

Dan carilah (pahala) negeri akhirat dengan apa yang telah dianugerahkan Allah kepadamu, tetapi janganlah kamu lupakan bagianmu di dunia dan berbuatbaiklah (kepada orang lain) sebagaimana Allah telah berbuat baik kepadamu, dan janganlah kamu berbuat kerusakan di bumi. Sungguh, Allah tidak menyukai orang yang berbuat kerusakan.

Terkait dengan ayat ini, Ibn Kathīr selain membicarakan konsep reward (pahala), yakni menggunakan pemberian Allah untuk mencapai pahala di dunia dan di akhirat (yahsulu laka bibā al-sawāb fì al-dunyà wa al-äkbirab), ${ }^{30}$ juga menyoroti hak-hak yang melekat dalam pemberian Allah. Hak-hak itu diperinci oleh Ibn Kathīr dengan hak untuk Allah, hak untuk diri sendiri, hak untuk keluarga, dan hak untuk sesama. Dalam tafsirnya, Ibn Kathīr menulis "fa àt kull żi ḥaqq haqqah" (berikanlah hak-hak kepada yang mempunyai hak (tersebut). ${ }^{31}$

Pemberian hak-hak ini berkelindan dengan redaksi ayat absin ka $m \bar{a}$ aḥsan Alläh ilayk. Ibn Kathīr menafsirkan dengan merujuk pada ayat lain, berbaiklah kamu sekalian kepada seluruh mahluk, sebagaimana Allah berbuat baik kepadamu. Pada akhir ayat QS. alQașaṣ:77 bisa dilihat perintah Allah yang tidak suka kepada hambaNya tatkala melakukan perbuatan yang merusak di muka bumi. Bahkan Ibn Kathīr memberikan catatan, jangan sampai ada dalam diri

29 Peraturan Pemerintah Pengganti Undang-undang Republik Indonesia Nomor 2 Tahun 2017 Tentang Perubahan atas Undang-undang Nomor 17 Tahun 2013 Tentang Organisasi Kemasyarakatan, 3.

30 Abū al-Fidā' al-Hāfiẓ b. Kathīr, Tafsìr al-Qứàn al-'Ažìm, vol. 3 (Beirut: Dār alFikr, 2011), 1406.

31 Ibid. 
seseorang muncul hasrat untuk berbuat buruk kepada setiap ciptaan Allah. ${ }^{32}$

Referensi ayat di atas, bisa ditarik tiga kata kunci yakni, keharusan memberikan kepada yang berhak, berbuat baik tanpa pandang bulu, dan juga larangan berbuat kerusakan. Ketiga kata kunci merupakan refrensial atas "ruang hidup" yang tidak boleh dirampas. Berkaitan erat dengan hak dan larangan melakukan kerusakan ini sebagaimana dijelaskan dalam QS. al-Rūm [30]: 41, memperingatkan:

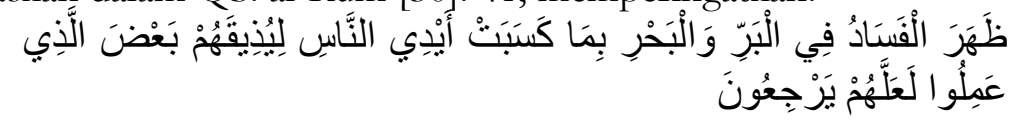

Telah tampak kerusakan di darat dan di laut disebabkan karena perbuatan tangan manusia; Allah menghendaki agar mereka merasakan sebagian dari (akibat) perbuatan mereka, agar mereka kembali (ke jalan yang benar).

Apabila dicermati, serangkaian perampasan ruang hidup, seperti konflik agraria, didasari atas pola yang sama yakni nafsu manusia yang hendak mendominasi manusia lain, pun alam. Bagaimana tidak, penciptaan ruang-ruang baru untuk melebarkan sayap kekuasaan, nyatanya menjadi awal bagaimana konflik muncul, sehingga perampasan ruang hidup terjadi. Persis seperti penjelasan Alquran, tepatnya QS. Yūsuf [12]: 53,

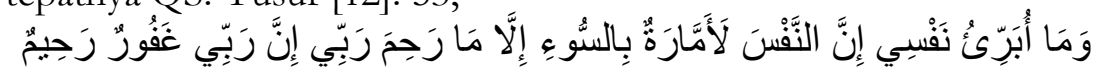

Dan aku tidak (menyatakan) diriku bebas (dari kesalahan), karena sesungguhnya nafsu itu selalu mendorong kepada kejahatan, kecuali (nafsu) yang diberi rahmat oleh Tuhanku. Sesungguhnya Tuhanku Maha Pengampun, Maha Penyayang.

Pada ayat lain bahkan disebut terdapat orang-orang yang menempatkan nafsu sebagai tuhannya, seperti penjelasan QS. alJāthiyah [45]: 23 dan al-Furquān [25]: 43-44,

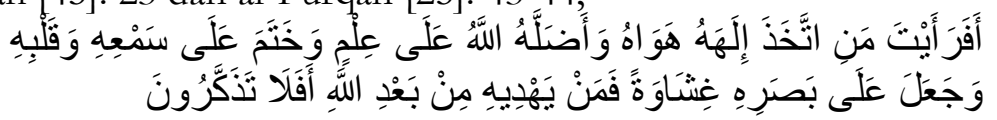

Maka pernahkah kamu melihat orang yang menjadikan hawa nafsunya sebagai tuhannya dan Allah membiarkannya sesat dengan sepengetahuan-Nya, dan Allah telah mengunci pendengaran dan hatinya serta meletakkan tutup atas penglihatannya? Maka siapa yang mampu memberinya petunjuk setelah Allah (membiarkannya sesat?) Mengapa kamu tidak mengambil pelajaran?

32 Ibid. 


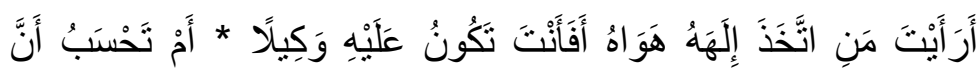

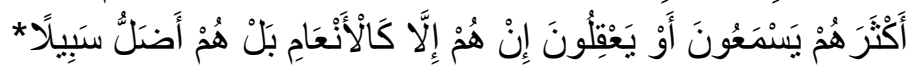

Sudahkah engkau (Muhammad) melihat orang yang menjadikan keinginannya sebagai tuhannya. Apakah engkau akan menjadi pelindungnya? Atau apakah engkau mengira bahwa kebanyakan mereka itu mendengar atau memahami? Mereka itu hanyalah seperti hewan ternak, bahkan lebih sesat jalannya.

Beberapa ayat di atas dengan jelas dan gamblang, menunjukkan bagaimana Alquran menggambarkan realitas manusia. Manusia yang diliputi hawa nafsu, bahkan mempertuhankannya. Peranan hawa nafsu ini, sebagaimana dipaparkan oleh Abdurrahaman Wahid (Gus Dur), memiliki kekuatan yang menyimpan potensi destruktif, dan menjadikan jiwa selalu resah dan tidak tenang. ${ }^{33}$ Dari perspektif ini, manusia berada dalam ittiba $\bar{a}^{\prime}$ al-nafs (mengikuti hawa nafsu), sebagaimana disebut dalam QS. al-Qașaṣ [28]: 50

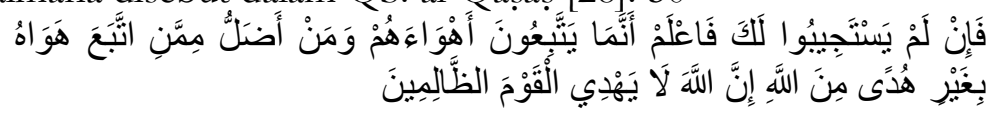

Maka jika mereka tidak menjawab (tantanganmu), maka ketahuilah bahwa mereka hanyalah mengikuti keinginan mereka. Dan siapakah yang lebih sesat daripada orang yang mengikuti keinginannya tanpa mendapat petunjuk dari Allah sedikit pun? Sungguh, Allah tidak memberi petunjuk kepada orang-orang yang zalim.

Dorongan nafsu manusia untuk berbuat zalim dengen selanjutnya membuat ilmu pengetahuan ditangguhkan begitu saja. Pada QS. alRūm [30]: 29 diketengahkan,

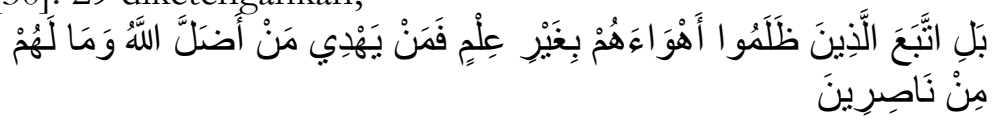

Tetapi orang-orang yang zalim, mengikuti keinginannya tanpa ilmu pengetahuan; maka siapakah yang dapat memberi petunjuk kepada orang yang telah disesatkan Allah. Dan tidak ada seorang penolong pun bagi mereka.

Dua kutipan ayat di atas memberikan penanda bahwa orang yang terliputi hawa nafsu, diberi identitas sebagai zalim. Secara bahasa zalim adalah tindakan kejahatan, dosa, kesewenang-wenangan, dan sebagainya. ${ }^{34}$ Kata zalim sendiri sudah terserap ke dalam bahasa Indonesia, disebutkan artinya sebagai tindakan "bengis, tidak menaruh

33 Abdurrahman Wahid (Ed.), Ilusi Negara Islam (Jakarta: Wahid Institute, Maarif Institute, 2009), 13.

${ }^{34}$ Muhammad b. Manẓur, Lisān al-'Arab, vol. 15 (tt: Dār al-fikr, t.th), 266. 
balas kasihan, tidak adil, dan kejam."35 Dari artikulasi tersebut tindakan zalim merupakan tidakan yang tidak berperikemanusian yang menabrak norma sosial maupun norma hukum. Masih pada ayat tersebut di atas, disebutkan bahwa tindakan zalim adalah tindakan tersesat.

Tidak hanya berhenti dalam pengertian di atas, bahwa pelaku zalim jika dianalisis melalui medan semantik pada sistem Qur'ani akan tampak banyak identitas lain yang melekat pada seorang zalim, seperti syirik, ${ }^{36}$ melanggar hukum Allah, ${ }^{37}$ fasik, ${ }^{38}$ kufur, ${ }^{39}$ sombong, ${ }^{40}$ tidak adil, ${ }^{41}$ dusta, ${ }^{42}$ dan sebagainya. Sampai di sini, menjadi penting dan dapat digarisbawahi, bahwa merampas ruang hidup adalah perbuatan zalim sebagaimana digambarkan dalam sistem Qur'ani dan secara fatal berakibat pada kerusakan. Dengan identitas tersebut, maka senyatalah bahwa pelaku zalim telah menihilkan aspek sosial dari tanah (yang merupakan kodratnya).

Berakar dari pemahaman di atas, maka menegakkan UU Negara dan HAM dengan meng-counter perampasan ruang hidup dapat dilakukan dengan penyadaran akan larangan agama mengikuti nafsu. Penyadaran ini penting, sebab akan meningkatkan standar kualitas diri sebagai umat beragama. Dalam Islam nilai fundamental dari agama adalah rahmat bagi seluruh alam. Tertuang dalam QS. al-Anbiyā' [21]: 107 ,

\section{وَمَا أَرْستلنَتَاكَ إِلَّا رَحْمَةً لِلْعَالَمِينَ}

Dan Kami tidak mengutus engkau (Muhammad) melainkan untuk (menjadi) rahmat bagi seluruh alam.

Prinsip rahmat bagi seluruh alam dalam Islam di atas mengandaikan upaya terus-menerus oleh pemeluknya, dalam hal ini manusia untuk selalu berperilaku dan bertindak sesuai koridor rahmat. Sikap ini mencakup kasih sayang, tidak zalim, tiada aktivitas yang merusak dan menyakiti kepada siapapun. Kepada manusia, hewan,

\footnotetext{
35 Departemen Pendidikan Nasional, Kamus bahasa Indonesia (Jakarta: Pusat Bahasa, 2008), 836.

${ }^{36}$ Lihat QS. Luqmān [31]: 13, QS. Hūd [11]: 101; QS. Yūnus [10]: 51.

${ }^{37}$ QS. al-Baqarah [2]: 229.

${ }^{38}$ QS. al-Baqarah [2]: 59.

${ }^{39}$ Lihat QS. al-Baqarah [2]: 254; QS. al-Furqān [25]: 4; QS. al-Rūm [30]: 29; QS. alA'rāf [7]: 23; QS. al-Shūrā [42]: 45.

${ }^{40}$ Lihat QS. Yūnus [10]: 52, 83 dan QS. al-Mu'minūn [23]: 74, 46.

${ }^{41}$ QS. Taha [20]: 112.

42 QS. al-'An‘ām [6]: 21.
} 
alam, dan semua makhluk. Kasih sayang senantiasa ditebarkan dan nafsu kezaliman dihilangkan.

\section{Menempatkan Ruang Hidup sebagai Simpul Social Capital}

Pada bagian ini, akan diulas, bagaimana tawaran yang ideal bagi pelanggaran HAM berupa perampasan ruang hidup dengan menilik kalaborasi teori sosial dan tafsir. Kasus perampasan ruang hidup yang cukup kompleks, bisa diminimalisasi dan/atau diselesaikan dengan menempatkan ruang hidup sebagai simpul (baca: titik temu) modal sosial (social capital). Pierre Bourdieu mendefenisikan modal sosial sebagai keseluruhan sumber konsep aktual atau potensial, yang dihubungkan dengan kepemilikan suatu jaringan yang tahan lama atau lebih kurang hubungan timbal balik antar institusi yang dikenalnya. ${ }^{43}$ Dalam bahasa yang lebih sederhana, pendefinisian modal sosial oleh Bourdieu ini ditemukan dalam paparan I.B. Wirawan, dengan kunci "hubungan sosial berharga antara orang-orang". ${ }^{44}$ Sementara Francis Fukuyama memberikan penejelasan modal sosial sebagai serangkaian nilai atau norma informal pemberi teladan yang digunakan bersama di antara anggota-anggota sebuah kelompok yang memungkinkan mereka saling bekerja sama. ${ }^{45}$

Hans Blomkvist dan Ashok Swain memberikan pandangan bahwa modalitas sosial mengacu pada rasa saling percaya, jaringan dan norma-norma bersama yang dimiliki oleh sekelompok aktor dalam mengejar kepentingan-kepentingan bersama. ${ }^{46}$ Pada titik ini, pendefinisian modal sosial bisa diambil kata kunci berupa rasa percaya, jaringan kerja sama, kepentingan bersama. Kata kunci yang demikian, dalam pandangan Alexis De Tocqueville merupakan serangkaian hubungan "win-win" yang di dalamnya setiap orang membawa manfaat. ${ }^{47}$ Dalam disiplin ilmu sosial, modal sosial merupakan anti-tesis dari pandangan Darwinisme. Tatkala Darwinisme menyebut manusia mempunyai insting struggle for life yang

\footnotetext{
43 Ghazali Syamni, "Profil Social Capital Suatu Kajian Literatur," dalam Jurnal Bisnis dan Ekonomi, vol. 17, no. 2 (2010), 174.

${ }^{44}$ I.B. Wirawan, Teori Sosial dalam Tiga Paradigma (Jakarta: Kencana, 2012), 277.

45 Chafid Wahyudi, Nabdlatul Ulama dan Civil Religion (Yogyakarta: Graha Ilmu, 2013), 17.

46 Ibid.

47 Ibid.
} 
digunakan untuk mempertahankan hidup, meski harus bersaing agar bisa survive, tidak berlaku demikian dalam konstruksi modal sosial. ${ }^{48}$

Modal sosial menempatkan kerja sama dalam pemenuhan kebutuhan. Bahwa kebutuhan dapat dipenuhi melalui jalan kerja sama. Sebab secara hakiki, sebagaimana disampaikan Fukuyama dalam The Great Dismption: Human Nature and the Reconstruction of Social Order, bahwa manusia pada dasarnya adalah makhluk sosial yang memiliki kemampuan bawaan untuk mengatasi masalah kerja sama sosial dan menciptakan aturan moral guna mengendalikan pilihan individu. Tanpa harus didesak manusia akan menciptakan ketertiban dengan sendirinya begitu ia memenuhi keperluan hidupnya sehari-hari dan bersinggungan dengan orang lain".

Berdasarkan atas hal tersebut, maka menempatkan modal sosial sebagai tawaran solusi atas perampasan ruang hidup berarti menempatkan masyarakat dalam sebuah jaringan kepercayaan. Artinya, ruang hidup dapat menjadi simpul dalam upaya merangkai modal sosial yang dimaksud. Simpul ini pada gilirannya akan membentuk satu jaringan kerjasama di masyarakat untuk mengatasi perampasan ruang hidup.

Pada level praktis, Fukuyama menyebut ada tiga item pararel yang dapat mewujudkan modal sosial. Tiga item yang dimaksud yakni trust (kepercayaan), reciprocity (hubungan timbal balik) dan collectivity (aksi bersama). ${ }^{50}$ Terkait trust ini, Giddens membaginya dalam dua tipe yang saling berkaitan. Pertama trust atas abstract system. Kedua, trust terhadap personal. Pada trust atas abstract system yakni adanya kepercayaan yang terbangun sebagai implikasi dari berfungsinya institusi-institusi publik dan pranata sosial yang baik. Sementara trust terhadap personal dimaksudkan sebagai kepercayaan yang terbangun sebagai implikasi adanya interaksi intim dan terus menerus antara individu yang satu dengan individu yang lain. ${ }^{51}$

Dalam hal ini, trust bisa dibangun melalui pijakan moral sebagai norma-norma informal dalam masyarakat. ${ }^{52}$ Menempatkan moral dan menjadikannya pintu masuk membangun trust bisa dimulai dengan penyemaian narasi kebersamaan, gotong royong, persaudaraan, yang

48 Haris El Mahdi \& Suryadi, "Menemukan Kembali Kapital Sosial Bangsa Indonesia," dalam Jurnal Interaktif, vol. 1, no. 1 (2010), 25.

49 Wahyudi, Nahdlatul Ulama,16-17.

${ }^{50}$ El Mahdi \& Suryadi, “Menemukan Kembali Kapital," 27.

${ }^{51}$ Ibid.

52 Wahyudi, Nabdlatul Ulama., 18. 
sebenarnya, merupakan moral yang telah menyatu dalam diri bangsa Indonesia. Pada gilirannya, moral tersebut menjadi unsur yang integratif-efektif dalam keragaman masyarakat, seiring dengan trust terhadap personal yang terbangun sebab hubungan intim.

Tatkala trust telah terbangun dalam masyarakat, bahwa saling percaya untuk bersama dan kerja sama, akan mengarah pada item kedua, sebagaimana disampaikan Fukuyama, yakni reciprocity. Item kedua ini memungkinkan terwujudnya hubungan timbal balik dan aksi bersama yang genuine. ${ }^{53}$ Adanya trust bahwa ruang hidup adalah kebutuhan bersama, lantas masyarakat melakukan hubungan timbal balik, pun aksi bersama mencegah perampasan ruang hidup agar tidak semakin menjadi-jadi.

Namun, pada level yang lebih hard, teori strukturasi Anthony Giddens juga memberikan pembacaan yang representatif terkait perampasan ruang hidup. Sebagai gambaran, Giddens dengan teori strukturasinya mencoba menjembatani perdebatan dua kubu teoritis besar, yakni yang menempatkan struktur sebagai perhatian utama, dan di sisi lain yang menempatkan aktor sebagai perhatian utama. ${ }^{54}$ Giddens berargumen, bahwa hal yang diperdebatkan dua kubu (baca: struktur dan aktor) dapat dilibatkan secara berulang dan berpola dalam lintas ruang dan waktu. Dalam hal ini, aktor merupakan hasil (outcome) dari struktur, tetapi aktor juga menjadi mediasi bagi pembentukan struktur baru. Ada hubungan timbal balik di antara keduanya. Giddens menempatkan tiga gugus besar dalam struktur. Pertama, struktur signifikansi, kedua, struktur dominasi, ketiga struktur legitimasi. ${ }^{55}$

Struktur signifikansi mengandaikan pengertian, menyangkut penyebutan dan wacana. Struktur dominasi, mencakup penguasaan atas orang dan barang. Sementara struktur legitimasi, menyangkut peraturan normatif yang terungkap dalam tata hukum. Terkait dengan aktor, Giddens menawarkan pembedaan dari dimensi internal. Pertama, motivasi tak sadar, kedua, kesadaran praktis, ketiga, kesadaran diskursif. ${ }^{56}$ Motivasi tak sadar berkaitan dengan keinginan atau kebutuhan yang berpotensi mengarah kepada tindakan. Kesadaran praktis menunjuk pada gugus pengetahuan praktis yang tidak selalu

\footnotetext{
${ }^{53}$ El Mahdi \& Suryadi, "Menemukan Kembali Kapital," 27.

54 Wirawan, Teori Sosial, 291.

55 Ibid., 314.

56 Ibid.
} 
bisa diurai. Sementara kesadaran diskursif, mengacu pada kapasitas merefleksi dan memberi penjelasan eksplisit atas tindakan yang telah dilakukan. ${ }^{57}$

Lebih lanjut, struktur signifikansi mengandaikan kesewenangan memerintah, yakni pemerintah, maka akan mengarah pada struktur dominasi, bahwa pemerintah punya kekuasaan mengatur masyarakat sesuai dengan ketentuan yang berlaku. Pada gugusan struktur legitimasi, pemerintah mempunyai kewenangan untuk menerapkan sanksi dan/atau hukuman tatkala terjadi suatu pelanggaran. Melalui struktur yang disebut sebelumnya menghasilkan aktor, akan membentuk aktor dengan tiga kesadaran yang disebut di atas. Dalam hal ini, struktur berupa aturan penyelenggaraan negara, yang menempatkan pemerintah sebagai penyelenggara, adalah aktor yang berproses dialektis dengan struktur. Termasuk juga masyarakat, yang merupakan aktor yang bisa terpengaruh dan mempengaruhi struktur. Satu catatan penting dalam penjelasan Giddens, ia menempatkan struktur lebih bersifat memberdayakan (enabling) yang memungkinkan berlangsungnya praktik-praktik sosial dalam masyarakat. Struktur ala Giddens ini, berbeda dengan apa yang disampaikan Dukrkhemian, bahwa struktur sangatlah mengekang masyarakat. ${ }^{58}$

Dalam kaitan dengan enabling-nya struktur ala Giddens, aturan penyelenggaraan negara yang menjadi struktur dapat memberdayakan aktor. Struktur bahwa aturan harus ditegakkan, dalam pandangan Giddens, tidak melulu kaku. Pemerintah dapat melakukan penegakan yang enabling, umpama dengan melakukan serangkaian penyadaran yang humanis dalam kaitannya dengan perampasan ruang hidup. Gugusan struktur dan aktor versi Giddens yang membentuk dualitas menjadi unsur yang saling melengkapi dalam menanggulangi perampasan ruang hidup.

Tilikan ilmu sosial yang menawarkan modal sosial (social capital) dan strukturasi sebagai penanggulangan perampasan ruang hidup, menjadi lebih lengkap dengan merujuk pada penjelasan dan tawaran ayat Alquran. Dalam hal ini, tawaran ayat Alquran atas perampasan ruang hidup dapat didasarkan atas QS. al-Mā’idah [5]: 2 yang berbunyi:

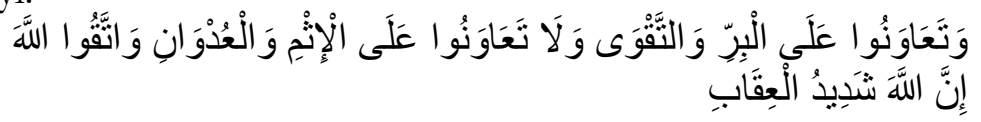

${ }^{57}$ Ibid.

58 Ibid., 313. 
Dan tolong-menolonglah kamu dalam (mengerjakan) kebajikan dan takwa, dan jangan tolong-menolong dalam berbuat dosa dan permusuhan. Bertakwalah kepada Allah, sungguh, Allah sangat berat siksaan-Nya.

Elaborasi atas ayat di atas, sebagaimana berpijak pada penejelasan Ibnu Kathīr, bahwa penanggulangan perampasan ruang hidup disedikan dengan kerangka controlling. Kerangka tersebut diamaksudkan, sebagai sebuah upaya sinergitas di antara masyarakat untuk menuju kebaikan. Sinergitas yang dimaksud terimplementasikan pada kontrol berupa saling mengingatkan, tatkala ada salah satu anggota masyarakat yang melakukan kesalahan. ${ }^{59}$ Tawaran ayat Alquran ini menjadi legitimasi dari agama Islam dalam menanggulangi perampasan ruang hidup. Saling mengingatkan adalah langkah yang juga tidak bisa diabaikan begitu saja dalam proses sosial. Dalam hal ini, hadis Nabi Muhammad riwayat dari Imam Aḥmad dapat menjadi penjelasan tawaran tersebut.

Suatu ketika Nabi Muhammad bersabda: "tolonglah saudaramu yang melakukan kezaliman atau yang dizalimi". Lalu sahabat merespons "bagaimana cara menolong orang yang dizalimi wahai Nabi?" Nabi Muhammad lantas menjawab "tabjizubu wa tamna"ubu min al-zulm fa dhäka nașub". Bahwa membatasi dan mencegah dari kezaliman adalah cara menolong orang yang melakukan kezaliman. Dalam riwayat lain, dengan redaksi yang berbeda, sebagaimana penuturan Thābit, Nabi Muhammad bersabda "tamna'uh min al-zulm fa dhäka nasruka iyyāh". Mencegah seorang yang melakukan kezaliman adalah caramu menolong mereka (yang melakukan kezaliman). ${ }^{60}$

Tentu dalam hal ini dapat dipahami, bahwa kezaliman yang dimaksud adalah melakukan perampasan ruang hidup, sebagai manifestasi terminologi zălim. Perampasan ruang hidup dikatakan sebagai kezaliman sebab perilaku ini tidak menempatkan ruang hidup pada tempat yang semestinya. Akibatnya, tidak hanya kerusakan ekologis yang menjadi ancaman, tetapi juga persoalan kesenjangan dan konflik sosial.

\section{Kesimpulan}

Sebagai hukum tertinggi, UUD 1945 telah menggariskan ketentuan kemanusiaan-keadilan sebagai nilai yang tak boleh absen

${ }^{59}$ Ibn Kathīr, Tafsì Al-Qur'ān, vol. 2, 548.

${ }^{60}$ Ibid. 
dalam penyelenggaraan negara. Namun di tataran lapangan, nilai tersebut tergerus, di antaranya terwujud melalui rangkaian konflik agraria, seperti perampasan ruang hidup. Dalam tinjauan HAM dan Alquran, bisa disimpulan bahwa perampasan ruang hidup adalah sebuah kesalahan. Dalam kacamata HAM, perampasan ruang hidup adalah pelanggaran atas hak hidup, yang dapat dikategorikan sebagai pelggaran atas HAM.

Semantara dalam tinjauan Alquran, melalui firman Allah pada QS. al-Qașaș [28]: 77, perampasan ruang hidup adalah pengingkaran atas perintah Allah, di mana Allah menggariskan untuk memberikan hak kepada yang berhak. QS. al-Rūm [30]: 41 memberikan potret pengingkaran atas perintah Allah merupakan sumber kerusakan, baik di bumi maupun laut. Sementara QS. al-Mā’idah [5]: 2 menggariskan sebuah ketentuan bahwa perampasan ruang hidup harus dihentikan, dan tiada tawar-menawar untuk saling membantu, sebab perampas ruang hidup telah melakukan sebuah kezaliman.

Tinjauan HAM dan Alquran atas perampasan ruang hidup yang demikian membawa pada suatu keniscayaan akan tawaran untuk menanggulanginya. Dari tilikan ilmu sosial, kerangka modal sosial (social capital) adalah solusi yang soft bagi permasalahan ruang hidup. Sementara tawaran yang hard, perspektif Strukturasi Giddens, memberikan pandangan bahwa struktur lah yang dapat memberdayakan, untuk menanggulangi permasalahan ruang hidup.

Terakhir, yang tidak kalah penting adalah bahwa ayat Alquran memberikan tawaran berupa sinergitas antar masyarakat untuk menanggulangi persoalan perampasan ruang hidup ini. Sinergitas yang dimaksud terwujud pada sikap saling mengingatkan di antara masyarakat, bahwa jika persoalan tersebut adalah kesalahan dan perlu dihindari bersama. Demikianlah amanat yang tertuang dalam firman Allah pada QS. al-Mā’idah [5]: 2.

\section{Daftar Pustaka}

Baso, Ahmad. Islam Pasca-Kolonial: Perselingkuban Agama, Kolonialisme, dan Liuberalisme. Bandung: Mizan, 2005.

D., Harvey. The New Imperialism. New York: Oxford University Press: 2003.

Dewan Kehutanan Nasional. Undang-undang nomor 5 Tabun 1960 tentang Peraturan Dasar Pokok-pokok Agraria, dalam http://dkn.or.id/wp- 
content/uploads/2013/03/Undang-Undang-RI nomor-5-Tahun1960-tentang-Pokok-Pokok-Dasar-Agraria.pdf.

Departemen Pendidikan Nasional. Kamus bahasa Indonesia. Jakarta: Pusat Bahasa, 2008.

Kathīr (ibn), Abī al-Fidā' al-Hafīz. Tafsìr al-Qur'ān al-'Až̀im. Beirut: Dār al-Fikr, 2011.

Manzūr (ibn), Muhammad. Lisān al-'Arab. t.t: Dār al-Fikr, t.th.

Mahfudh, Hasan. 'Dari Ibrahim M. Abu Rabi' tentang Problematika

Studi Islam Kontemporer." Millati: Journal of Islamic Studies and Humanities, vol. 1, no. 1 (2016).

Majelis Permusyawaratan Rakyat Republik Indonesia. 2013. Undangundang Dasar Negara Republik Indonesia Tabun 1945. Jakarta: Sekretariat Jendral MPR RI.

Mujahid, Ahmad. "Pandangan Mufasir Indonesia Terhadap Isu-Isu Hak Asasi Manusia." Mutawatir: Jurnal Keilmuan Tafsir Hadith, vol. 9, no. 2 (2019).

Kamali, Mohammad Hashim. Membumikan Syariah, terj. Miki Salman. Bandung: Mizan, 2013.

Kansil, C.S.T., Christine S.T. Kansil, Pengantar Ilmu Hukum Indonesia. Jakarta: Rineka Cipta, 2011.

Kementrian Keuangan. "Penjelasan atas Undang-undang Nomor 5 tahun 1960 tentang Undang-undang Pokok Agraria" dalam http://www.jdih.kemenkeu.go.id/fullText/1960/5TAHUN 196 OUUPENJEL.htm

Kenshanahan, Agaton. "Sejarah dan Pengertian Lebensraum." http://abroadlythinking.blogspot.com/2015/08/sejarah-danpengertian-lebensraum.html. Diakses pada 26 April 2020.

Konsorsium Pembaruan Agraria. "Perampasan Ruang Hidup oleh Pemilik Hak atas Tanah.” http://www.kpa.or.id/news/blog/ perampasan-ruang-hidup-oleh-pemilik-hak-atas-tanah/ Diakses pada 26 April 2020.

Pambudi, Teguh. "Yesus dan Keadilan Ruang Hidup." https://kristenhijau.wordpress.com/2017/05/25/yesus-dankeadilan-ruang-hidup-2/

Peraturan Pemerintah Pengganti Undang-undang Republik Indonesia Nomor 2 Tahun 2017 Tentang Perubahan atas Undang-undang Nomor 17 Tahun 2013 Tentang Organisasi Kemasyarakatan, 3. 
Safitri, Myrna A. \& Tristam Moeliono. Hukum Agraria dan Masyarakat di Indonesia. Jakarta: HuMa; Van Vollenhoven Institute; KITLVJakarta, 2010.

Setiawan, Eka Wahyu. "Politik Ruang Hidup dan perampasan Ruang Hidup Masyarakat." https://indoprogress.com/2018/03/politikruang-dalam-perampasan-ruang-hidup-masyarakat/

Syamni, Ghazali. "Profil Social Capital Suatu Kajian Literatur." Jurnal Bisnis dan Ekonomi, vol. 17, no. 2 (2010).

El Mahdi, Haris \& Suryadi. "Menemukan Kembali Kapital Sosial Bangsa Indonesia.” Jurnal Interaktif, vol. 1, no. 1 (2010).

Undang-undang Nomor 5 Tahun 1960 tentang Peraturan Dasar Pokok-pokok Agraria.

Undang-undang Republik Indonesia Nomor 39 Tahun 1999 Tentang Hak Asasi Manusia.

Wahid, Abdurrahman (ed.). Ilusi Negara Islam. Jakarta: Wahid Institute, Maarif Institute, 2009.

Wahyudi, Chafid. Nahdlatul Ulama dan Civil Religion. Yogyakarta: Graha Ilmu, 2013.

WALHI Jawa Timur. "Mendiami Negeri yang Tak Layak Huni Catatan Lingkungan Hidup Jawa Timur 2016." http://walhijatim.or.id/2017/01/mendiami-negeri-yang-taklayak-huni-catatan-lingkungan-hidup-jawa-timur-2016/

Wirawan, I.B. Teori Sosial dalam Tiga Paradigma. Jakarta: Kencana, 2012. 